\title{
10. Women as Candidates and Voters: Gender Issues and the Kerema Open Electorate
}

\author{
Orovu Sepoe
}

\section{Introduction}

The 2007 national election in Papua New Guinea was expected to produce some pronounced changes in terms of its administration and conduct, and in the final outcome, particularly as a result of the introduction of a limited preferential voting (LPV) system. Certainly, a lot more work and higher costs were involved in administering the election, partly due to the lengthy counting process associated with LPV. In terms of its outcomes, the winners obtained a larger mandate from the voters than in previous elections. While some observers commented that electoral violence was quelled as a result of LPV, others posited that a heavy deployment of security forces was primarily responsible for the more peaceful election.

From a gender perspective, it was anticipated that women candidates would have far greater chance of success at the polls given the element of preference trading implicit in LPV and the widely accepted view that LPV could be anybody's game. This, however, did not eventuate. It is important to understand why the 2007 election outcome, like all other elections in the past, did not prove to be advantageous for women. The main objective of this study is therefore to examine women as candidates and voters, with specific reference to gender issues in the Kerema Open electorate.

The discussion and analysis here are based on personal observations of campaigning and polling as well as election information made available by the Papua New Guinea Electoral Commission (PNGEC), in particular the final election results. In addition to media coverage, four local research assistants based in the Gulf Province through all phases of the election provided invaluable information about the election.

The chapter is presented in three parts. The first briefly outlines the conceptual basis for the study. The second gives an overview of women's participation and gender issues in the 2007 national election. The final part is a discussion of women as candidates and voters, and analysis of gender issues, in Kerema Open. 


\section{Conceptual framework}

The discussion and analysis in this study is premised on several theoretical and conceptual tools relevant to the gender and feminist perspective.

First, the public/private split in social, economic and political realms of life infiltrates the entire electoral process. The prevailing cultural perceptions of men as the decision-makers results in the continuing domination of public leadership positions and roles by men. The large number of male candidates compared to female candidates not only demonstrates this perception but also reinforces it. The domination of political parties by men, and the relatively low endorsement of women candidates compared to men, further supports this view. The prevailing trend is for women candidates not to be taken seriously by political parties. Women's role in cooking and hospitality during campaign rallies and feasts supports prevailing gender norms and division of labour. As voters, women's choices are mostly determined or dictated by men.

Secondly, the concepts of structure and agency allow us to understand women's position relative to men as the dominant players while also accounting for women's empowerment in a male-dominated system. The persistent view of electoral politics as a male preserve is reflected, for example, in the number of guns in the hands of 'warlord' candidates, and in access to and control over resources such as money and labour. 'Bigman' leadership style sends a clear message that women cannot be 'bigmen'. However, it is important not to lose sight of the ever-increasing number of women contesting as candidates in Papua New Guinea elections, even standing against sitting MPs who are apparently well established and well resourced (Elizabeth Simogun Bade's challenge to Sir Michael Somare in the East Sepik Provincial seat recalls the biblical story of David and Goliath). The evidence of women's participation in politics demonstrates the empowerment of increasing numbers of women courageous and confident enough to challenge male candidates in a male-dominated sphere.

Thirdly, the idea of the state as a masculine entity entails an appreciation of the implications of women's entry to the electoral process, which poses immense challenges and difficulties for women as candidates and voters. These include the heavy presence and involvement of security forces; electoral violence and intimidation, whose perpetrators are mostly men; the expenses associated with security during the election, which is essentially money spent on problems created by men; and the predominance of money politics, which illustrates male control of public and private resources.

Fourthly, the issue of women's rights as human rights requires appreciation of the fact that the Constitution of Papua New Guinea grants women the right to vote and stand for public office. Questions need to be asked: how is the electoral 
process ensuring that women's rights are exercised? What is the role of the state (specifically the PNGEC and the security forces) and of civil society in defending the rights of women? Is the cultural context supportive of women's rights? Is the political environment conducive for women to exercise their rights, especially with widespread corruption, bribery, violence and intimidation?

Finally, analyses of women's participation in politics have to acknowledge the concepts of difference, diversity and commonality. Women are divided by religion, culture, age, education, socio-economic class, rural-urban divide, and so on. This could explain why women voters are not voting for women candidates, or are even contesting against each other.

\section{Gender issues in the 2007 national election}

\section{Women as candidates}

A total of 103 women candidates contested the 2007 national election (3.7 percent of the total of 2759 candidates), showing an upward trend in numbers of women candidates in most post-independence elections (Table 10.1). A list of women candidates, showing the electorate contested and party affiliation in 2007, is given in Table 10.8 in the appendix at the end of this chapter. Of these, 39 (37.9 percent) were nominated by political parties while 64 nominated as independents - fewer than in 2002, when 49 claimed party affiliation. It is highly likely that some of the independents in 2007 were in fact pro-party candidates, a practice quite common in Papua New Guinea politics. ${ }^{1}$

Table 10.1: Women in national elections, 1972-2007

\begin{tabular}{cccccc}
\hline Year & $\begin{array}{c}\text { Total } \\
\text { candidates }\end{array}$ & $\begin{array}{c}\text { Number } \\
\text { of female } \\
\text { candidates }\end{array}$ & $\begin{array}{c}\text { Percent } \\
\text { of female } \\
\text { candidates }\end{array}$ & $\begin{array}{c}\text { Female } \\
\text { candidates } \\
\text { with party } \\
\text { affiliation }\end{array}$ & $\begin{array}{c}\text { Female } \\
\text { candidates } \\
\text { elected }\end{array}$ \\
\hline 1972 & 608 & 4 & 0.7 & na & 1 \\
1977 & 879 & 10 & 1.1 & 1 & 3 \\
1982 & 1124 & 17 & 1.5 & 0 & 1 \\
1987 & 1515 & 18 & 1.3 & 7 & 0 \\
1992 & 1655 & 16 & 1.0 & 0 & 0 \\
1997 & 2372 & 55 & 2.3 & 12 & 2 \\
2002 & 2870 & 71 & 2.5 & 49 & 1 \\
2007 & 2759 & 103 & 3.7 & 39 & 1 \\
\hline
\end{tabular}

1 Personal communication (December 2007) with two female candidates who nominated as independents but received some financial support from a political party. 
Some provinces had more women candidates than others, the highest (12 women) being Eastern Highlands and the lowest (one woman) Bougainville and West New Britain (Table 10.2). For the first time in history, all 20 provinces had women contesting the national election.

Table 10.2: Provincial distribution of women candidates, 2007 election

\begin{tabular}{lclc}
\hline & Rank & Province & Number of candidates \\
\hline Highest number of & 1 & Eastern Highlands & 13 \\
women candidates & 2 & Oro & 11 \\
& 3 & Milne Bay & 9 \\
& 3 & Central & 9 \\
\hline Lowest number of & 18 & East New Britain & 2 \\
women candidates & 19 & Bougainville & 1 \\
& 19 & West New Britain & 1 \\
\hline
\end{tabular}

On a regional basis, the Southern Region had the highest number of women candidates (45), followed by the Highlands Region (27), Momase (22) and the Islands Region (9). Generally, the peaceful nature of elections in the Southern Region has encouraged women to contest. However, the Highlands Region, by far the most volatile and high-risk region, was ranked second. This may be largely explained by the work of civil society organizations in promoting principles of good governance and democracy, including rights of women, peace, and law and order. ${ }^{2}$

Of the 34 registered political parties, 22 endorsed women candidates. The number of party-endorsed women candidates, however, fell from 49 in 2002 to 39 in 2007. The largest number was recorded by People's Action Party ( 5 candidates) and the Melanesian Alliance (4 candidates). The Pan Melanesian Congress, New Generation Party and National Alliance endorsed 3 women candidates each. Three political parties endorsed 2 women candidates each while 14 other political parties endorsed 1 candidate each. These figures are low, and suggest that parties have yet to consider women seriously. The fact that the People's Action Party (of which Janet Sape is deputy president) and the Melanesian Alliance (of which Dame Carol Kidu is parliamentary leader) endorsed the largest number of women candidates also illustrates the importance of having women actively involved in political parties to exert influence in decisions about candidate selection.

The Organic Law on the Integrity of Political Parties and Candidates (OLIPPAC) appears to have done little so far to encourage political parties to endorse female

2 In this regard, the work of Kup Women for Peace (see chapter 11), Meri i Kirap Sapotim and other nongovernment organizations carrying out election awareness is acknowledged. 
candidates. Political parties are fixed on getting the 'strongest', most 'popular' candidates, mostly men, though these are not necessarily the best candidates, and often poll poorly.

In relation to policies, women candidates generally focused on social, welfare, family, good governance and rights issues. ${ }^{3}$ They did not necessarily reflect party policies, even for women endorsed by political parties. This was partly to do with the fact that party endorsements were slow in coming and that preparations for campaigning, including policy platforms, were finalized well before party endorsements were confirmed. It also illustrates the nature of party affiliation: parties and candidates do not necessarily have long-term relationships, a reflection of the weak party system in Papua New Guinea. Many of the female candidates endorsed by parties, like male candidates, neither were members nor had long-term affiliation with those parties.

Some women candidates had experience as community leaders (civil society organizations/non-government organizations) and professionals (in both the private and public sectors). 'Money politics' and corruption, however, deny women candidates a level playing field.

\section{Women as voters}

Women voters appeared to exercise free choice in Kerema, though their preferences were mostly predetermined. Elsewhere, intimidation of women voters ranged from obvious, through subtle to non-existent.

However, just as the OLIPPAC seems to have had little impact on the mindset of political parties, LPV did little or nothing to change the perception and mindset of women voters, who seem (at least on the basis of observation in Kerema) to have generally preferred male leadership. The cultural and social environment remains largely unchanged.

3 This became apparent in a post-election diagnostic workshop for women candidates held at UPNG, 19-22 November 2007, sponsored by the United Nations Development Programme. 


\section{Gender issues and the election in Kerema Open electorate}

\section{Women as candidates}

Three women candidates contested the Kerema Open seat, two from coastal areas and one from inland - the latter an historical first. One of the three had contested the seat in 2002. Two of the women had non-government organization leadership experience; the other was a primary school teacher.

Two of the women stood as party-endorsed candidates - though lacking any long-term political party affiliation - and one stood as an independent. ${ }^{4}$ None of the women candidates undertook electorate-wide campaigning, campaign activities being essentially restricted to their own language and cultural areas for both coastal and inland candidates. One candidate could barely meet her election expenses. After a frantic search for funds from women's organizations, ${ }^{5}$ her nomination fee was provided by her son just before the close of nomination, and she was hard pressed to make it to Kerema in time to nominate.

One of the women (who had contested in 2002) had lost her husband close to nomination. Some people said: 'She is a widow; doesn't she respect her husband?' Because her husband was from another province, it was suggested that her allegiance should be to her husband's people.

Resource constraints were encountered by all women candidates. In comparison to some of the male candidates, mobility was restricted; without access to private transport (motorized dinghies or vehicles) all three campaigned mostly on foot. No candidate posters for the women were seen in villages or along roadsides or main travel routes. There was no money for feasting or to bribe voters. However, it was alleged that one woman candidate had accessed donor funding for LPV awareness and used it to her advantage in carrying out awareness about her candidacy.

\section{Women as voters}

Voters' general attitude towards women candidates was one of indifference. None of the women candidates was considered popular in the electorate, though a few voters considered that one of the three women was more qualified than

4 This candidate was in fact a pro-party candidate (personal communication with the candidate, December 2007).

5 I am aware that she approached Papua Hahine Social Action Forum and Women in National Government Strategy for Change during the polling period. 
most of the male candidates. There was little awareness of notions of 'women's rights' or 'gender equality'. Rural voters in Kerema Open have little time for such principles - indeed, the identity of women candidates was challenged by ordinary village women, who saw their lifestyle as far removed from those of rural women. Some voters expressed the view that the candidates needed to be on the ground to experience villagers' hardships and understand their lives (a comment equally applicable to male candidates). But most were simply not aware of women's candidacy.

In Kerema women voters generally follow the dictates of their husband or male relatives; failure to stick by the family choice could result in rejection and conflicts (post-election events attest to this, where family relations have soured as a result of election choices). Cultural norms are still strong and women are not taken seriously as leaders who can represent their people in parliament. In some cases, 'money politics' compelled voters, including women, to vote for men.

On the other hand, women performed their gender roles as hosts, feeding campaign teams, and wives and female relatives of male candidates were actively involved in rallying support, especially for husbands from a different cultural area. Family networks were revived to build and draw voter support; every family connection was utilized and, in this respect, women were key linkages through marriage.

Women also had much influence on how resources-especially food-were distributed: how much to whom? Who to look after? Elections are a time to eat and drink, and women at the fireplaces had much more than they would normally consume. Women also received cash rewards for their efforts.

However, there is evidence of changing perceptions, and some women and men are supporting women candidates, acknowledging that the quality of some male candidates was poor compared to women candidates.

\section{Election outcome for women candidates in Kerema Open}

Tables 10.3 to 10.6 show the election results for women candidates in Kerema Open. Table 10.3 suggests that all female candidates received their primary votes from their respective ethnic communities (as represented by local-level government [LLG] areas) - though this is not confined to female candidates, as most male candidates also received most of their votes from their respective ethnic (LLG) communities.

Table 10.4 shows primary and final votes for the women candidates, their respective placing and when they were eliminated from the count. Table 10.9 in the appendix to this chapter shows the same for all candidates, indicating voter support for men in comparison to women candidates. 
It is apparent from Tables 10.4 and 10.5 that women as voters did not give their primary votes to female candidates, either from choice or because their votes were predetermined by male kin.

Informal votes for the inland LLG areas, Kaintiba and Kotidanga, where illiteracy rates are very high, were, paradoxically, very low (at 0.8 and 0.7 percent respectively). By comparison, the informal votes registered in the coastal LLG areas were between 2 and 5 percent (Table 10.6). This may be attributed to the abuse of 'assisted voting', where the bulk of ballot papers were marked by 'helpers'. ${ }^{6}$

\section{Table 10.3: Female candidates' and selected male candidates' primary votes and percentages by local-level government areas, Kerema Open electorate, 2007}

\begin{tabular}{|c|c|c|c|c|c|c|c|c|}
\hline \multirow[t]{2}{*}{ No. } & \multirow[t]{2}{*}{ Candidate name } & \multicolumn{6}{|c|}{$\begin{array}{l}\text { Total and percentage of primary votes received in } \\
\text { each local-level government area }\end{array}$} & \multirow[t]{2}{*}{ Total } \\
\hline & & KU & СК & EK & $\mathbf{K}$ & кOTI & TL & \\
\hline \multirow[t]{2}{*}{12} & Kathy Karapa Tom & 4 & 23 & 3 & 6 & 2 & 5 & 43 \\
\hline & & 9.3 & 53.5 & 7.0 & 14.0 & 4.7 & 11.6 & 100.0 \\
\hline \multirow[t]{2}{*}{19} & Pricilla Opa Kare & 3 & 581 & 6 & 0 & 5 & 35 & 630 \\
\hline & & 0.5 & 92.2 & 1.0 & 0.0 & 0.8 & 5.6 & 100.0 \\
\hline \multirow[t]{2}{*}{35} & Josephine W Morova & 4 & 9 & 3 & 191 & 1105 & 136 & 1448 \\
\hline & & 0.3 & 0.6 & 0.2 & 13.2 & 76.3 & 9.4 & 100.0 \\
\hline \multirow[t]{2}{*}{16} & Pittom Titus Bombom & 91 & 39 & 21 & 3427 & 74 & 122 & 3774 \\
\hline & & 2.4 & 1.0 & 0.6 & 90.8 & 2.0 & 3.2 & 100.0 \\
\hline \multirow[t]{2}{*}{51} & George Mero & 235 & 370 & 2221 & 17 & 183 & 303 & 3329 \\
\hline & & 7.1 & 11.1 & 66.7 & 0.5 & 5.5 & 9.1 & 100.0 \\
\hline \multirow[t]{2}{*}{20} & Dan F P Maravila & 352 & 104 & 10 & 0 & 2 & 43 & 511 \\
\hline & & 68.9 & 20.4 & 2.0 & 0. & 0.4 & 8.4 & 100.0 \\
\hline \multirow[t]{2}{*}{55} & Nixon Forova & 26 & 19 & 435 & 0 & 1 & 8 & 489 \\
\hline & & 5.3 & 3.9 & 89.0 & 0.0 & 0.2 & 1.6 & 100.0 \\
\hline \multirow[t]{2}{*}{28} & Richard Panama & 16 & 9 & 1 & 178 & 1779 & 137 & 2120 \\
\hline & & 0.8 & 0.4 & 0.0 & 8.4 & 83.9 & 6.5 & 100.0 \\
\hline \multirow[t]{2}{*}{14} & Sivore Lakou & 5 & 24 & 45 & 0 & 4 & 686 & 764 \\
\hline & & 0.7 & 3.1 & 5.9 & 0.0 & 0.5 & 89.8 & 100.0 \\
\hline
\end{tabular}

Key: Kerema Urban (KU), Central Kerema (CK), East Kerema (EK), Kaintiba (K), Kotidanga (KOTI), Tauri Lakekamu (TL)

\footnotetext{
6 At the time of writing, a petition was before the Court of Disputed Returns relating to allegations that the 'helpers' were supporters of the winner.
} 
Table 10.4: Female candidates, votes, placing and elimination, Kerema Open electorate, 2007

\begin{tabular}{clccccc}
\hline No. & Candidate name & $\begin{array}{c}\text { Primary } \\
\text { votes }\end{array}$ & $\begin{array}{c}\text { Primary } \\
\text { placing }\end{array}$ & $\begin{array}{c}\text { Final } \\
\text { votes }\end{array}$ & $\begin{array}{c}\text { Final } \\
\text { placing }\end{array}$ & Elimination \\
\hline 12 & Kathy Karapa Tom & 43 & 47 & 43 & 47 & 5 th \\
19 & Priscilla Opa Kare & 630 & 16 & 1190 & 13 & 39th \\
5 & Josephine W Morova & 1448 & 5 & 3614 & 4 & 48th \\
\hline
\end{tabular}

Table 10.5: Eligible voters by local-level government area, Kerema Open electorate, 2007

\begin{tabular}{lcccc}
\hline LLGs & Male & Female & Total & Total on roll \\
\hline Kerema Urban & 855 & 865 & 1,720 & 2,800 \\
Central Kerema & 3,410 & 3,090 & 6,500 & 8,300 \\
East Kerema & 3,622 & 3,084 & 6,706 & 9,400 \\
Kaintiba & 2,799 & 2,235 & 5,034 & 6,700 \\
Kotidanga & 3,523 & 3,063 & 6,586 & 9,300 \\
Tauri Lakekamu & 2,493 & 1,990 & 4,483 & 7,700 \\
Total eligible voters & 16,702 & 14,327 & 31,029 & 44,200 \\
\hline
\end{tabular}

Table 10.6: Total formal and informal votes by local-level government area, Kerema Open electorate, 2007

\begin{tabular}{lccccccc}
\hline Ballot papers & KU & CK & EK & K & KOTI & TL & Total \\
\hline Total formal votes & 1,648 & 6,296 & 6,540 & 5,087 & 6,584 & 4,384 & 30,539 \\
Total informal votes & 72 & 206 & 194 & 39 & 45 & 116 & 672 \\
Total votes & 1,720 & 6,502 & 6,734 & 5,126 & 6,629 & 4,500 & 31,211 \\
Percent informal votes & $(4.2)$ & $(3.2)$ & $(2.9)$ & $(0.8)$ & $(0.7)$ & $(2.6)$ & $(2.2)$ \\
\hline
\end{tabular}

Key: Kerema Urban (KU), Central Kerema (CK), East Kerema (EK), Kaintiba (K), Kotidanga (KOTI), Tauri Lakekamu (TL)

\section{Conclusion}

The 2007 national election saw many more women contesting than in the 2002 election, continuing the upward trend observed since the first postindependence election in 1977.

However, money politics, as well as entrenched cultural perceptions and practices, effectively ruled out any chance of free and fair electoral competition for women candidates. Support for increased women's entry into parliament is not ingrained in the mindset of voters, men or women. Reforms, such as the OLIPPAC and the change to LPV, appear to have done little, if anything, to change this. 
Meanwhile, behind the scenes women performed their gender roles, hosting campaign teams and utilizing family connections and linkages through marriage to rally support for husbands and male relatives.

\section{References}

Post-Election Diagnostic Workshop for Women Candidates, University of PNG, November 2007. UNDP, UNIFEM Pacific and AusAID in partnership with Department of Commuity Development and National Council of Women.

\section{Appendix}

\section{Table 10.7: Voting statistics for Kerema Open electorate, 2007 election}

\begin{tabular}{lrr}
\hline Number of registered voters & 42,160 \\
Total votes cast & 31,205 & \\
Informal votes & 508 & (1.6\% of total votes cast) \\
Total allowable ballot papers & 30,697 & \\
Total ballot papers remaining in count & 11,428 \\
Total votes distributed & 23,594 \\
Exhausted ballot papers & $19,269 \quad$ (62.8\% of allowable ballots) \\
Absolute majority $(50 \%+1)$ & 5,715 & \\
\hline
\end{tabular}

Table 10.8: Female candidates in the 2007 election

\begin{tabular}{llll}
\hline Name & Province & Electorate & Party affiliation \\
\hline Odelia Virua & East New Britain & Gazelle Open & Independent \\
Rosemary Vartuam Swek & East New Britain & Rabaul Open & Independent \\
Ruth Mandra Kuma & Manus & Manus Open & Independent \\
Cathy Lee Graham & New Ireland & Kavieng Open & Independent \\
Helen Fong Seeto & New Ireland & Kavieng Open & Independent \\
Monica Maleigua & New Ireland & Kavieng Open & Independent \\
Anna Ofu & Central & Kairuku-Hiri Open & Independent \\
Lady Rita Kipalan & Central & Kairuku-Hiri Open & Independent \\
Maria Andrew Laut & Central & Goilala Open & Independent \\
Philomena Kassman & Central & Central Provincial & Independent \\
Veronica Aawa Bera & Central & Kairuku-Hiri Open & Independent \\
Waila Koloa & Central & Rigo Open & Independent \\
Cathy Karapa Tom & Gulf & Kerema Open & Independent \\
Susan Ila Apopo & Gulf & Kikori Open & Independent \\
Dinah Halstead & Milne Bay & Alotau Open & Independent \\
Judy Kauadi & Milne Bay & Samarai-Murua Open & Independent \\
& & &
\end{tabular}


10. Women as Candidates and Voters: Gender Issues and the Kerema Open Electorate

\begin{tabular}{|c|c|c|c|}
\hline Name & Province & Electorate & Party affiliation \\
\hline Leah Sharp & Milne Bay & Milne Bay Provincial & Independent \\
\hline Matilda May Pilacapio & Milne Bay & Alotau Open & Independent \\
\hline Selina Elijah & Milne Bay & $\begin{array}{l}\text { Kiriwina Goodenough } \\
\text { Open }\end{array}$ & Independent \\
\hline Helen Robert & $\begin{array}{l}\text { National Capital } \\
\text { District }\end{array}$ & $\begin{array}{l}\text { Moresby North East } \\
\text { Open }\end{array}$ & Independent \\
\hline Margaret Kliawi & $\begin{array}{l}\text { National Capital } \\
\text { District }\end{array}$ & $\begin{array}{l}\text { Moresby North West } \\
\text { Open }\end{array}$ & Independent \\
\hline Margret Morris & $\begin{array}{l}\text { National Capital } \\
\text { District }\end{array}$ & $\begin{array}{l}\text { Moresby North East } \\
\text { Open }\end{array}$ & Independent \\
\hline Mary J Karo & $\begin{array}{l}\text { National Capital } \\
\text { District }\end{array}$ & Moresby South Open & Independent \\
\hline Anita Yapuso & Oro & Oro Provincial & Independent \\
\hline Clare Embahe Nenai & Oro & Oro Provincial & Independent \\
\hline Deborah Eupu Emboge & Oro & Ijivitari Open & Independent \\
\hline Josephine M Abajah & Oro & Sohe Open & Independent \\
\hline Oliva Aripa Bunari & Oro & Oro Provincial & Independent \\
\hline Shirley Otto Jipori & Oro & Oro Provincial & Independent \\
\hline Ageda Mili & Western & Middle Fly Open & Independent \\
\hline Naomi Kamai & Western & North Fly Open & Independent \\
\hline Julie Trasis Kuri & Chimbu & Chimbu Provincial & Independent \\
\hline Miriam Waie Kia & Chimbu & $\begin{array}{l}\text { Karamui-Nomane } \\
\text { Open }\end{array}$ & Independent \\
\hline Rhonda Gande Baru & Chimbu & $\begin{array}{l}\text { Karamui-Nomane } \\
\text { Open }\end{array}$ & Independent \\
\hline Botty Usima & Eastern Highlands & Bura-Wonenara Open & Independent \\
\hline Ellen Hamena & Eastern Highlands & Lufa Open & Independent \\
\hline Esta Siru Joshua & Eastern Highlands & Kainantu Open & Independent \\
\hline Florence Jaukae & Eastern Highlands & Goroka Open & Independent \\
\hline Julie Soso Akeke & Eastern Highlands & $\begin{array}{l}\text { Eastern Highlands } \\
\text { Provincial }\end{array}$ & Independent \\
\hline Linet Mofeno & Eastern Highlands & Henganofi Open & Independent \\
\hline Rhonda Morris Risepe & Eastern Highlands & Kainantu Open & Independent \\
\hline Robyn Belari nenda & Eastern Highlands & Daulo Open & Independent \\
\hline Susan Sam Fima & Eastern Highlands & Henganofi Open & Independent \\
\hline Maryanne Tokome Amu & Enga & Wapenamanda Open & Independent \\
\hline Auana Janet Koriama & $\begin{array}{l}\text { Southern } \\
\text { Highlands }\end{array}$ & Tari Open & Independent \\
\hline Anna Nepa & $\begin{array}{l}\text { Western } \\
\text { Highlands }\end{array}$ & $\begin{array}{l}\text { Western Highlands } \\
\text { Provincial }\end{array}$ & Independent \\
\hline Doris K Kentz & $\begin{array}{l}\text { Western } \\
\text { Highlands }\end{array}$ & Jimi Open & Independent \\
\hline Elizabeth Simogun Bade & East Sepik & East Sepik Provincial & Independent \\
\hline Evangeline Kaima & East Sepik & Wewak Open & Independent \\
\hline Jennifa Bowie & East Sepik & Wewak Open & Independent \\
\hline
\end{tabular}


Election 2007: The Shift to Limited Preferential Voting in Papua New Guinea

\begin{tabular}{|c|c|c|c|}
\hline Name & Province & Electorate & Party affiliation \\
\hline Josepha Namsu Kiris & East Sepik & Wewak Open & Independent \\
\hline Margretha Apakia & East Sepik & Wosera Gawi Open & Independent \\
\hline Betty Rugei Higgins & Madang & Usino Bundi Open & Independent \\
\hline Cecilia Pakule & Madang & Madang Open & Independent \\
\hline Margaret Yusam & Madang & Usino Bundi Open & Independent \\
\hline Mary Kamang & Madang & Madang Provincial & Independent \\
\hline Delilah Kelly & Morobe & Tewae-Siaso Open & Independent \\
\hline Gusu Tuhiana & Morobe & Finschaffen Open & Independent \\
\hline Julie Kandi & Morobe & Nawae Open & Independent \\
\hline Loujaya Toni & Morobe & Lae Open & Independent \\
\hline Coretta Lema Naig & West Sepik & $\begin{array}{l}\text { Vanimo-Green River } \\
\text { Open }\end{array}$ & Independent \\
\hline Lena Miroi Napmuku & West Sepik & West Sepik Provincial & Independent \\
\hline Lespina Pupuwes & West Sepik & $\begin{array}{l}\text { Vanimo-Green River } \\
\text { Open }\end{array}$ & Independent \\
\hline Marry Tarp Lene & West Sepik & Telefomin Open & Independent \\
\hline Rita Jonah & Oro & Sohe Open & Christian Party \\
\hline Anne Karo Karafae & Eastern Highlands & Henganofi Open & $\begin{array}{l}\text { Mapai Levites } \\
\text { Party }\end{array}$ \\
\hline Elizeberth Mary Sipos & Manus & Manus Open & $\begin{array}{l}\text { Melanesian } \\
\text { Alliance }\end{array}$ \\
\hline Hilda Timan Kakawi & West New Britain & Talasea Open & $\begin{array}{l}\text { Melanesian } \\
\text { Alliance }\end{array}$ \\
\hline Dame Carol Kidu & $\begin{array}{l}\text { National Capital } \\
\text { District }\end{array}$ & Moresby South Open & $\begin{array}{l}\text { Melanesian } \\
\text { Alliance }\end{array}$ \\
\hline Lilias Erepa Klapat & Oro & Sohe Open & $\begin{array}{l}\text { Melanesian } \\
\text { Alliance }\end{array}$ \\
\hline Matilda Tagu Koma & Central & Goilala Open & $\begin{array}{l}\text { Melanesian Liberal } \\
\text { Party }\end{array}$ \\
\hline Maureen Ambo & Oro & ljivitari Open & National Alliance \\
\hline Laottie Miriam Laurie & Eastern Highlands & Kainantu Open & National Alliance \\
\hline Agatha Yama & Madang & Madang Open & National Alliance \\
\hline Priscilla Opa Kare & Gulf & Kerema Open & $\begin{array}{l}\text { National } \\
\text { Conservative Party }\end{array}$ \\
\hline Jollyn Ambo Warome & Eastern Highlands & $\begin{array}{l}\text { Eastern Highlands } \\
\text { Provincial }\end{array}$ & $\begin{array}{l}\text { National } \\
\text { Conservative Party }\end{array}$ \\
\hline Monica Abia Aitsi & Central & Central Provincial & $\begin{array}{l}\text { New Generation } \\
\text { Party }\end{array}$ \\
\hline Maggie Wilson & $\begin{array}{l}\text { Western } \\
\text { Highlands }\end{array}$ & Hagen Open & $\begin{array}{l}\text { New Generation } \\
\text { Party }\end{array}$ \\
\hline Donna Harvey Hall & Morobe & Bulolo Open & $\begin{array}{l}\text { New Generation } \\
\text { Party }\end{array}$ \\
\hline Goini Doilegu Loko & Milne Bay & Alotau Open & $\begin{array}{l}\text { Pan Melanesian } \\
\text { Congress }\end{array}$ \\
\hline
\end{tabular}


10. Women as Candidates and Voters: Gender Issues and the Kerema Open Electorate

\begin{tabular}{|c|c|c|c|}
\hline Name & Province & Electorate & Party affiliation \\
\hline Margaret Bacca & Milne Bay & Esa'ala Open & $\begin{array}{l}\text { Pan Melanesian } \\
\text { Congress }\end{array}$ \\
\hline Kruo Martha Kaiun & Chimbu & Kerowagi Open & $\begin{array}{l}\text { Pan Melanesian } \\
\text { Congress }\end{array}$ \\
\hline Damarise Buaga & Oro & Oro Provincial & $\begin{array}{l}\text { Papua and New } \\
\text { Guinea Unity Party }\end{array}$ \\
\hline Erigere Singin & Morobe & Nawae Open & $\begin{array}{l}\text { Papua and New } \\
\text { Guinea Unity Party }\end{array}$ \\
\hline Ruffina Peter & Central & Goilala Open & $\begin{array}{l}\text { Papua New Guinea } \\
\text { Party }\end{array}$ \\
\hline Martha Kala & Gulf & Kikori Open & $\begin{array}{l}\text { People's Action } \\
\text { Party }\end{array}$ \\
\hline Sahara Douglas & Milne Bay & Alotau Open & $\begin{array}{l}\text { People's Action } \\
\text { Party }\end{array}$ \\
\hline Janet Sape & $\begin{array}{l}\text { National Capital } \\
\text { District }\end{array}$ & NCD Provincial & $\begin{array}{l}\text { People's Action } \\
\text { Party }\end{array}$ \\
\hline Julie Moide & Western & North Fly Open & $\begin{array}{l}\text { People's Action } \\
\text { Party }\end{array}$ \\
\hline $\begin{array}{l}\text { Dr Donna Plamnok } \\
\text { Bikainbo }\end{array}$ & West Sepik & Telefomin Open & $\begin{array}{l}\text { People's Action } \\
\text { Party }\end{array}$ \\
\hline Susan Trose Mati & Eastern Highlands & Kainantu Open & $\begin{array}{l}\text { People's } \\
\text { Democratic } \\
\text { Movement }\end{array}$ \\
\hline Margret Kawa & $\begin{array}{l}\text { Southern } \\
\text { Highlands }\end{array}$ & Ialibu-Pangia Open & People's First Party \\
\hline Maria Micjeal Menap & Western & North Fly Open & $\begin{array}{l}\text { People's Freedom } \\
\text { Party }\end{array}$ \\
\hline Lynette Ona & Bougainville & $\begin{array}{l}\text { Central Bougainville } \\
\text { Open }\end{array}$ & People's Party \\
\hline Bella Eari Ameu & Oro & Sohe Open & $\begin{array}{l}\text { People's Progress } \\
\text { Party }\end{array}$ \\
\hline Edna Kathy Kakaraya & Enga & Enga Provincial & $\begin{array}{l}\text { People's Progress } \\
\text { Party }\end{array}$ \\
\hline Regina Aiarak & Western & North Fly Open & $\begin{array}{l}\text { People's Resources } \\
\text { Awareness Party }\end{array}$ \\
\hline Rhonda Gaiosi Anakapa & Milne Bay & Alotau Open & $\begin{array}{l}\text { PNG Conservative } \\
\text { Party }\end{array}$ \\
\hline Julie Daniel & Enga & Wabag Open & PNG First Party \\
\hline Monica Hasimani & East Sepik & $\begin{array}{l}\text { Yangoru-Saussia } \\
\text { Open }\end{array}$ & PNG Labour Party \\
\hline Epiya Janet Kang Nisa & $\begin{array}{l}\text { Southern } \\
\text { Highlands }\end{array}$ & Ialibu-Pangia Open & Star Alliance Party \\
\hline Josephine Wasi Morova & Gulf & Kerema Open & United Party \\
\hline Theresia Noglai & Chimbu & Kerowagi Open & Yumi Reform Party \\
\hline
\end{tabular}


Election 2007: The Shift to Limited Preferential Voting in Papua New Guinea

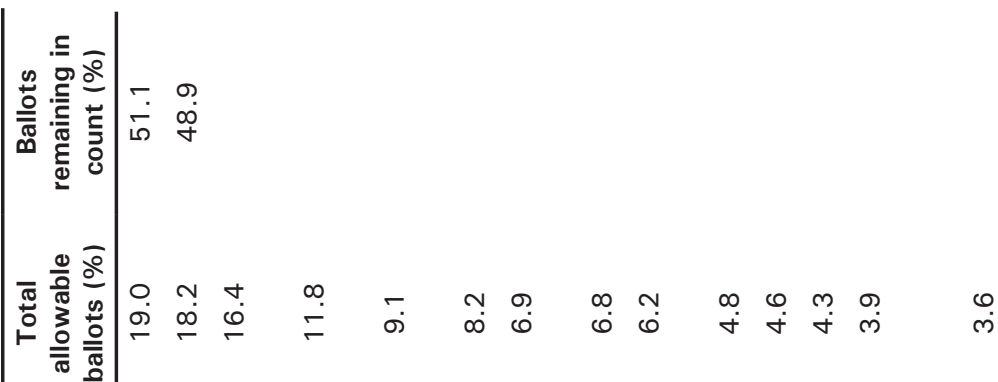

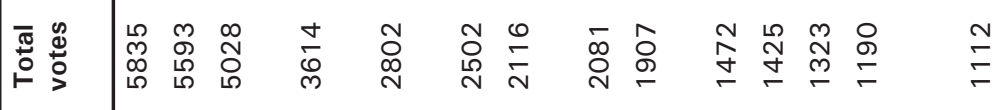

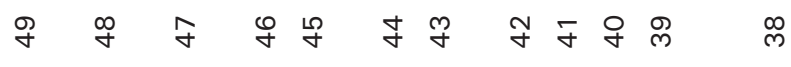

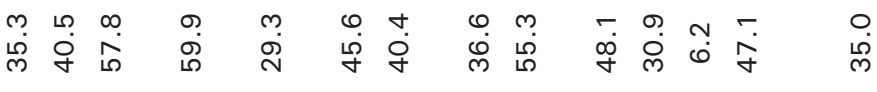

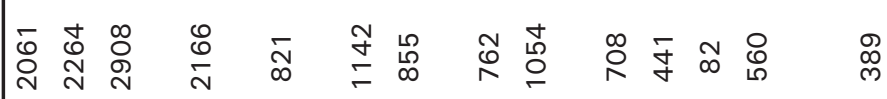

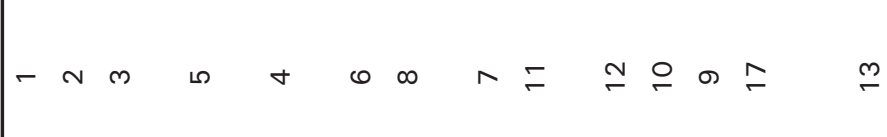

$$
\begin{aligned}
& \text { 등 응 }
\end{aligned}
$$

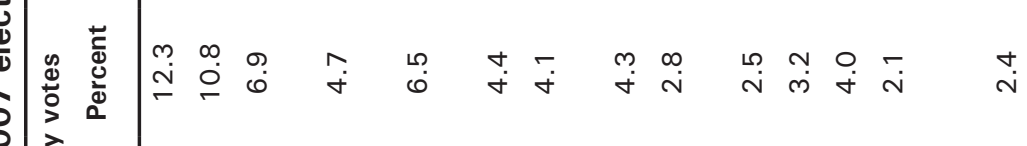

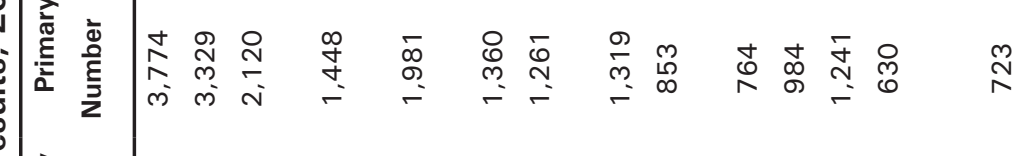

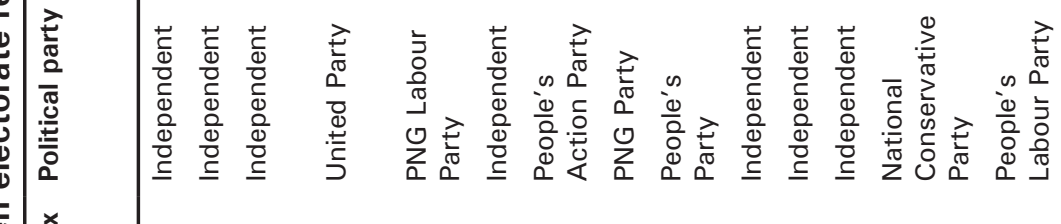

$$
\begin{aligned}
& \text { 帝 }
\end{aligned}
$$$$
\text { 잉 }
$$ 
10. Women as Candidates and Voters: Gender Issues and the Kerema Open Electorate

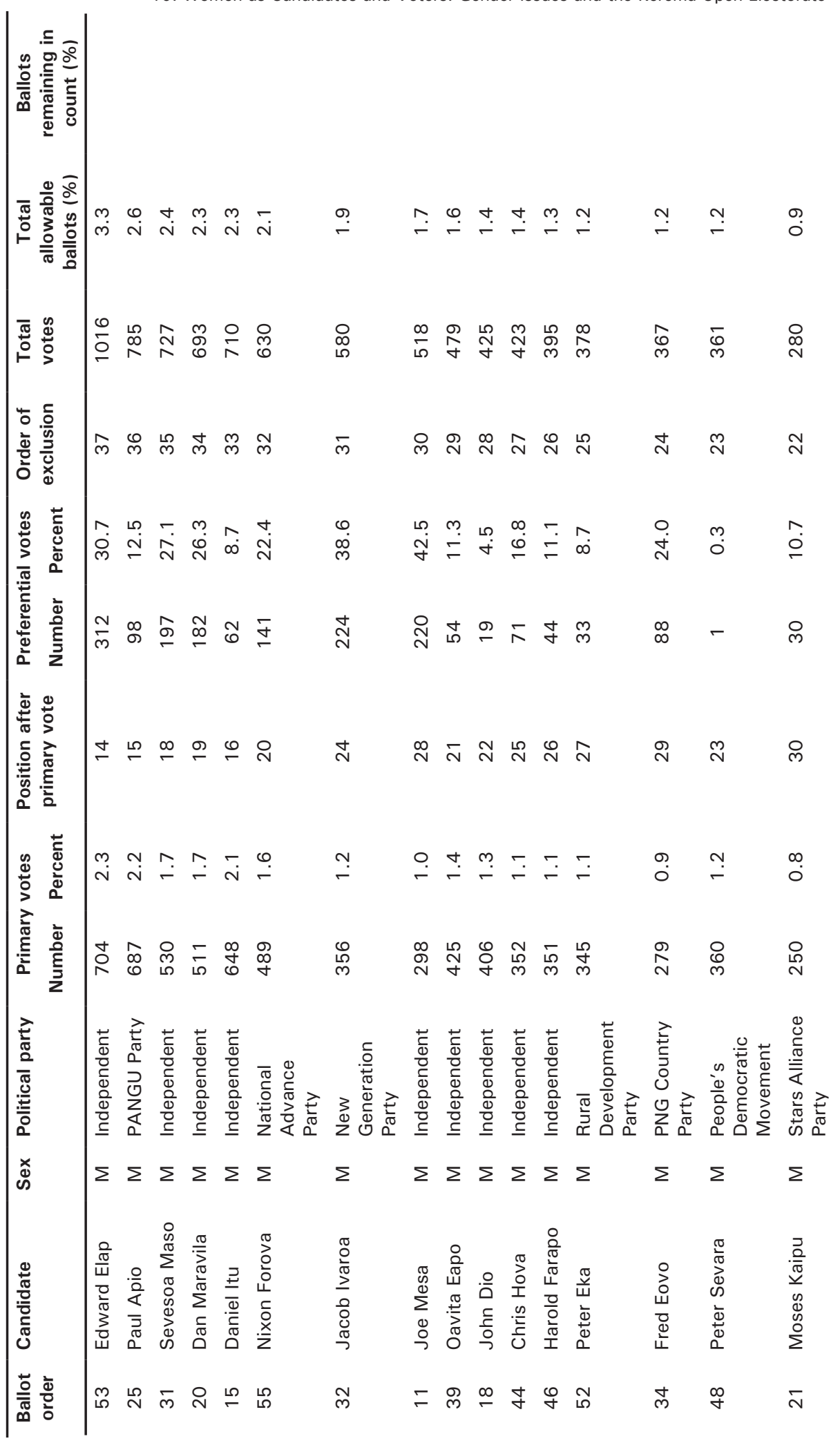


Election 2007: The Shift to Limited Preferential Voting in Papua New Guinea

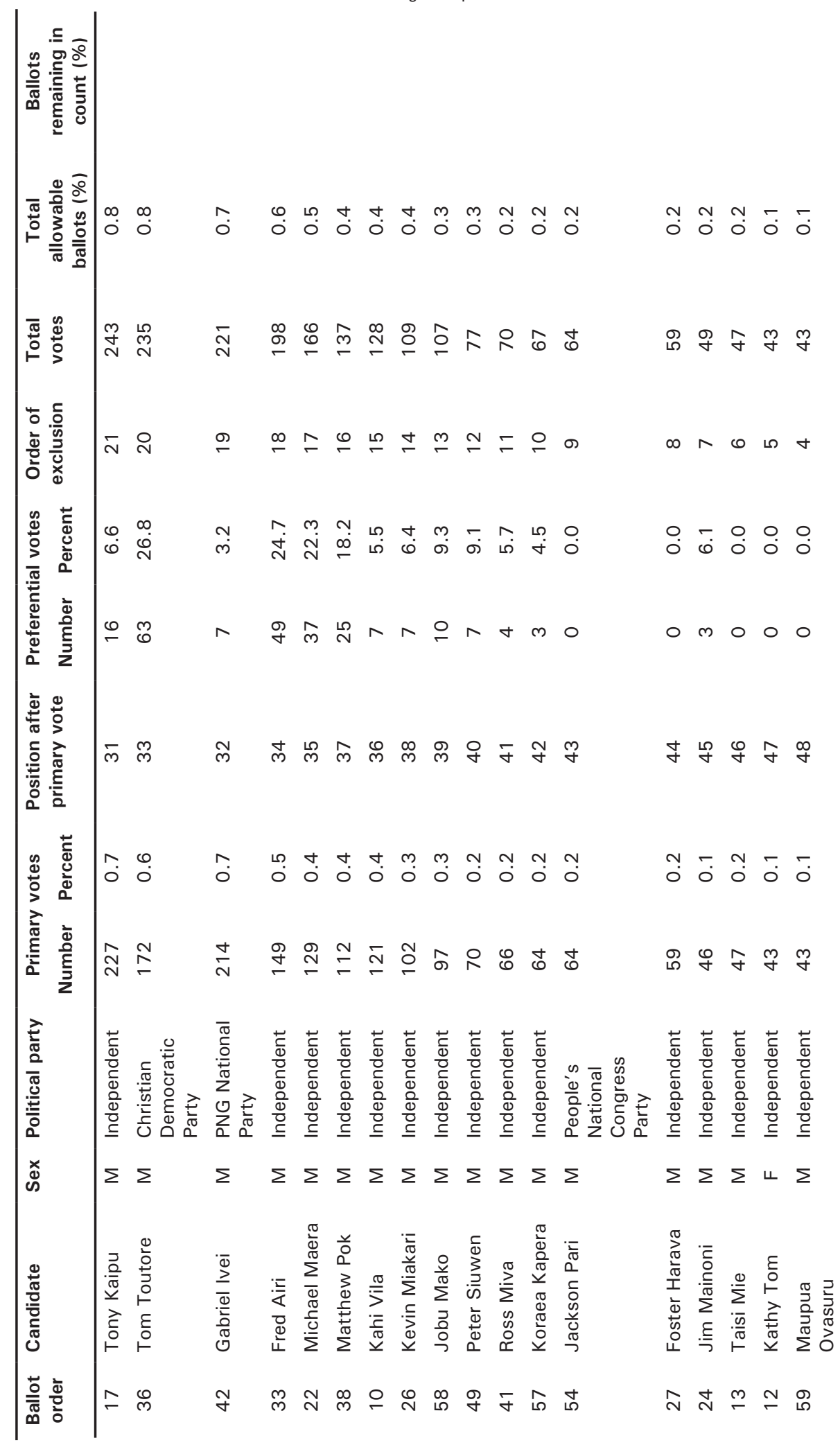


10. Women as Candidates and Voters: Gender Issues and the Kerema Open Electorate

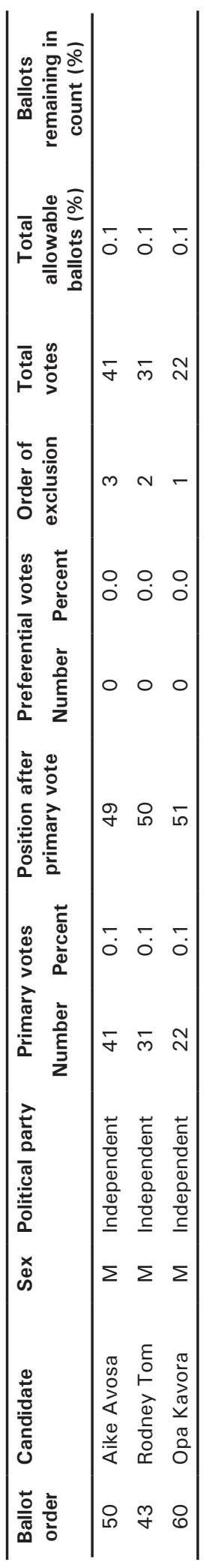

